\title{
Identifying priority management of Ecuadorian forests based on the environmental integrated assessment
}

\author{
Silvia Llerena $^{1 *}$, Priscila Arias ${ }^{1}$, Jhonn Cueva $^{2}$, Georgina Almeida $^{3}$, and Cristian Salazar ${ }^{1}$ \\ ${ }^{1}$ Peoples' Friendship University of Russia (RUDN University), Faculty of Ecology, 6 Miklukho- \\ Maklaya St, Moscow, 117198, Russian Federation \\ ${ }^{2}$ Peoples' Friendship University of Russia (RUDN University), Agrarian and Technological Institute, \\ 6 Miklukho-Maklaya St, Moscow, 117198, Russian Federation. \\ ${ }^{3}$ Peoples' Friendship University of Russia (RUDN University), Engineering academy, 6 Miklukho- \\ Maklaya St, Moscow, 117198, Russian Federation.
}

\begin{abstract}
Anthropogenic impacts, such as deforestation, soil erosion, and carbon dioxide emissions, have a negative influence over global warming due to the increase of $\mathrm{CO}_{2}$ levels in the atmosphere. The sustainable forest management is a way to mitigate climate change owing to the carbon storage capacity of forests. This study highlights the priority of forest management according to the integrated assessment of carbon storage under anthropogenic impacts in the administrative units of Ecuador. In the obtained map, the provinces Guayas, Esmeraldas, and Manabí showed the highest values of 25, 22.85 and 19.9, respectively, followed by two Amazon provinces, Morona Santiago and Sucumbíos. Therefore, we concluded that deforestation, soil erosion, and carbon dioxide emissions were more pronounced on the coast mainly due to agriculture and livestock activities and the forests in these provinces must have priority management. This analysis is useful for planning environmental practices in order to increase carbon storage as a strategy of mitigation for global warming.
\end{abstract}

\section{Introduction}

The world is suffering several global changes due to an unbalance between the human population increase and the capacity of the resources to sustain the increasing demand in the ecosystem services. Magrin and colleagues explain how the anthropogenic impacts such as deforestation, soil degradation, and human emissions have contributed to climate change [1], being deforestation the second-largest source of anthropogenic greenhouse gas (GHG) emissions [2]. The direct effect of deforestation is the decrease of carbon reservoirs and sinks. Furthermore, the loss of trees, which retains the soil with its roots, causes soil erosion that leads to additional carbon losses [3]. The sustainable management of forests, which includes forest conservation and restoration, reducing hazards, and maintaining forest

\footnotetext{
* Corresponding author : alellerenag@gmail.com
} 
health, is one mechanism to reduce the impacts of anthropogenic pressures. It is an effective way of climate change mitigation because forests have the capacity for carbon uptake and storage it in biomass and soils.

In Ecuador like in other Latin American countries, the anthropogenic impacts have released GHG to the atmosphere. Ecuador emits approximately 80,6 million tons per year of greenhouse gases because of the energy sector, land-use change and forestry, agriculture, industry, bunker fuels, and wastes. The second place of GHG emissions is occupied by land degradation and deforestation with 25,35\% [4,5]. Even though Ecuador is responsible for only $0.15 \%$ of greenhouse gases, it is one of the most affected by the fragility of its ecosystems. In response, Ecuador pledged to limit 2019-2025 GHG emissions to $9 \%$ in energy, industrial processes, wastes, and agriculture sectors; and additionally, a $4 \%$ reduction in the land use and land-use change sector, which includes deforestation and land degradation. In addition, a total reduction of $20.9 \%$ and $20 \%$ in the above-mentioned sectors could be achieved with the support of alliances and international cooperation management [4].

To reduce emissions in the sector of land-use change and forestry, governmental and non-governmental institutions have initiated various measures. In 2016, Ecuador presented its REDD+ Action Plan: Forests for the Good Living 2016-2025 to fight deforestation and protect forests. The aim of the REDD + Action Plan is to contribute to national efforts to reduce deforestation and forest degradation through conservation, sustainable forest management, and optimization of other land uses to reduce pressure on forests [6]. The Socio Bosque Program (SBP) is another forest conservation strategy, which gives monetary incentives to private forest owners and indigenous community. Additionally, Ecuador has 54 protected natural areas in forest ecosystems [7].

The identification, assessment, forecast, and protection of forests with high carbon sequestration can optimize resources and ensure the effectiveness of forest management strategies $[8,9,10,11]$. The priority conservation areas for carbon sequestration, which are territory defined by environmental characteristics threatened by human activities or natural causes [12], have already been used to promote the reduction of high rates of deforestation and restore degraded areas in other countries [13,14]. In Ecuador, there are deforestation studies related to change of land use, demography, and agricultural production [15]. Nevertheless, an integrated assessment of environmental indicators such as deforestation, carbon dioxide emissions and soil erosion over forest carbon storage is non-existent, which is the objective in this study.

The integrated assessment allows evaluating multiple parameters of different regions in order to identify situations with more urgent attention [16, 17]. This study includes the integrated assessment of the environmental indicators of anthropogenic impacts over forest carbon storage in administrative units of Ecuador. The result is a map of forest management for identifying conservation priority areas for natural resource protection.

\section{Materials and Methods}

Our research consisted of three stages: (1) collecting data of deforestation, anthropogenic soil erosion, carbon dioxide emissions, biomass, and organic carbon; (2) an integrated assessment with environmental indicators based on the collected data; and (3) the development of a forest management priority map based on integral factor values.

$\mathrm{n}$ the initial stage, the data were acquired from different sources. The deforestation data between 2008 and 2014 were obtained from the Ministry of the Environment of Ecuador [18], the erosion index from a scientific study about erosion [19] and the $\mathrm{CO}_{2}$ emissions from the National Institute of Statistics and Censuses of Ecuador [20]. The data 
of biomass and carbon storage in tons per hectare belong to the National Forestall Evaluation Project [21]. Table 1 summarizes the data used in this work.

Table 1. Deforestation, erosion, $\mathrm{CO}_{2}$ emissions, biomass and organic carbon data

\begin{tabular}{|c|c|c|c|c|c|}
\hline Provinces & $\begin{array}{c}\text { Deforestation } \\
\text { (ha/year) }\end{array}$ & $\begin{array}{c}\text { Erosion } \\
\text { index (\%) }\end{array}$ & $\begin{array}{c}\mathbf{C O}_{\mathbf{2}} \\
\text { emissions (t) }\end{array}$ & $\begin{array}{c}\text { Biomass } \\
\text { (t/ha) }\end{array}$ & $\begin{array}{c}\text { Organic } \\
\text { Carbon (t/ha) }\end{array}$ \\
\hline Azuay & 1039 & 75 & 4303.45 & 246.2 & 123.1 \\
\hline Bolívar & 2939 & 75 & 839.32 & 246.2 & 123.1 \\
\hline Cañar & 365 & 25 & 938.19 & 246.2 & 123.1 \\
\hline Carchi & 74 & 75 & 1231.61 & 246.2 & 123.1 \\
\hline Chimborazo & 42 & 755 & 1914.28 & 246.2 & 123.1 \\
\hline Cotopaxi & 1619 & 75 & 1882.1 & 246.2 & 123.1 \\
\hline El Oro & 4274 & 75 & 10240.93 & 74.08 & 37.04 \\
\hline Esmeraldas & 5476 & 75 & 2206.53 & 166.68 & 83.34 \\
\hline Guayas & 2570 & 50 & 44114.44 & 173.26 & 85.63 \\
\hline Imbabura & 246 & 75 & 4167.13 & 246.2 & 123.1 \\
\hline Loja & 1815 & 75 & 1457.26 & 95.82 & 47.91 \\
\hline Los Ríos & 395 & 25 & 7625.12 & 245.54 & 122.77 \\
\hline Manabí & 1411 & 100 & 12291.16 & 74.08 & 37.04 \\
\hline Morona Santiago & 7925 & 75 & 2440.2 & 320.8 & 160.4 \\
\hline Pichincha & 408 & 75 & 22912.15 & 246.2 & 123.1 \\
\hline Santo Domingo & 679 & 75 & 3228.23 & 246.2 & 123.1 \\
\hline Sucumbíos & 5416 & 75 & 2440.2 & 151.6 & 75.8 \\
\hline Tungurahua & 487 & 75 & 2994.34 & 210.2 & 105.1 \\
\hline
\end{tabular}

Once all data had been collected, interval scales for each Environmental Indicator (E.I.) were developed by using SPSS software (Table 2):

Table 2. Interval scales for indicators

Environmental indicator 1. Deforestation between 2008 and 2014 (ha/year).

\begin{tabular}{|c|c|c|c|c|}
\hline $1 .-<500$ & 2.- $500-1000$ & 3.- $1000-2500$ & 4.- $2500-5000$ & 5.- $>5000$ \\
\hline
\end{tabular}

Environmental indicator 2. $\mathrm{CO}_{2}$ emissions (t) 2011.

\begin{tabular}{|l|l|l|l|l|}
\hline $1 .-<1000$ & $2 .-1000-2000$ & $3 .-2000-4000$ & $4 .-4000-10500$ & $5 .->10500$ \\
\hline
\end{tabular}

Environmental indicator 3. Erosion index (\%) 2011.

\begin{tabular}{|l|l|l|l|l|}
\hline 1.- 0 None & 2.- 25 Potential & 3.- 50 Act. & 4.- 75 Pot. a. & 5.- 100 Very a. \\
\hline
\end{tabular}

Environmental indicator 4. Biomass in forests (t/ha) 2013.

\begin{tabular}{|l|l|l|l|l|}
\hline $1 .-<95$ & $2 .-95-150$ & $3 .-150-200$ & $4 .-200-250$ & $5 .->250$ \\
\hline
\end{tabular}

Environmental indicator 5. Carbon Capture by forest (t/ha) 2013.

\begin{tabular}{|l|l|l|l|l|}
\hline $1 .-<75$ & $2 .-75-100$ & $3 .-100-125$ & $4 .-125-150$ & $5 .->150$ \\
\hline
\end{tabular}

According to the interval scales, a numerical value between 1 and 5 was assigned to each E.I. of each province. Then, using these assigned values, weight coefficients regarding the urgency of management were proposed for each E.I. based on the Delphi technique and the qualimetry method in [22]. A weight coefficient whose numerical value is ' 2 ', corresponds to the most urgent state and the less immediate state is quantified with ' 0,5 '. Finally, the interval scale number ( 1 to 5) was multiplied by the weight coefficient for each environmental indicator. The results of these multiplications and the integral factors, which are calculated as the sum of the mentioned products by province, are reported in Table 3. 
The map of forest management priority according to the environmental indicators of anthropogenic impacts over forest carbon storage in Ecuador (Fig. 1) was developed based on the integral factor and using the graphics editor InkScape.

Table 3. Integral factor for forest management priority

\begin{tabular}{|c|c|c|c|c|c|c|c|}
\hline Provinces & E.I. 1 & E.I. 2 & E.I. 3 & E.I. 4 & E.I. 5 & $\begin{array}{c}\text { Integral } \\
\text { factor }\end{array}$ & $\begin{array}{c}\text { Priority } \\
\text { Management }\end{array}$ \\
\hline Azuay & 2.4 & 2.8 & 6 & 2 & 3 & 16.2 & Low \\
\hline Bolivar & 6 & 0.5 & 6 & 2 & 3 & 17.5 & Low \\
\hline Cañar & 0.6 & 0.5 & 1 & 2 & 3 & 7.1 & Very low \\
\hline Carchi & 0.5 & 1.2 & 6 & 2 & 3 & 12.7 & Low \\
\hline Chimborazo & 0.5 & 1.2 & 6 & 2 & 3 & 12.7 & Low \\
\hline Cotopaxi & 3 & 1.2 & 6 & 2 & 3 & 15.2 & Low \\
\hline El Oro & 7.5 & 4 & 6 & 0.5 & 1 & 19 & High \\
\hline Esmeraldas & 8.75 & 2.1 & 6 & 3 & 3 & 22.85 & High \\
\hline Guayas & 6 & 10 & 3 & 3 & 3 & 25 & High \\
\hline Imbabura & 0.5 & 2.8 & 6 & 2 & 3 & 14.3 & Low \\
\hline Loja & 3 & 1.2 & 6 & 2 & 2 & 14.2 & Low \\
\hline Los Ríos & 0.6 & 2.8 & 1 & 2 & 3 & 9.4 & Very low \\
\hline Manabí & 2.4 & 5 & 10 & 0.5 & 2 & 19.9 & High \\
\hline Morona Santiago & 10 & 2.1 & 6 & 1.3 & 1.3 & 20.7 & High \\
\hline Pichincha & 0.6 & 7.5 & 6 & 2 & 3 & 19.1 & Moderate \\
\hline Santo Domingo & 1.4 & 2.1 & 6 & 2 & 3 & 14.5 & Low \\
\hline Sucumbíos & 8.75 & 2.1 & 6 & 3 & 3 & 22.85 & High \\
\hline Tungurahua & 1.4 & 2.1 & 6 & 2 & 3 & 14.5 & Low \\
\hline
\end{tabular}

\section{Results and discussion}

Our results revealed that the forest management priority is concentrated on Guayas region (Fig. 2), the principal environmental indicator that encourages this behavior is the carbon dioxide emission (44114,44 ton), followed by the deforestation rate (Table 1 and Figure 1). Agricultural and aquaculture expansion has contributed to the deforestation and soil erosion, which release large amounts of carbon retained in the soil. In this area, mangrove zones predominate, which at a global scale can retain almost $1000 \mathrm{t} \mathrm{C} /$ ha, approximately three to four times higher than other tropical forest types [23]. Thus, forest management strategies are needed to conserve these remaining forests, an initiative is the implemented plan in 2009 by the National Forest Assessment of Ecuador (ENF, for its initials in Spanish language: Evaluación Nacional Forestal del Ecuador). The main aims of the ENF were to provide data and information for decision-making and development of public policies for Sustainable Forest Management and to meet the requirements for accessing to international carbon market for periodical forest monitoring over the long term [24].

Esmeraldas' forest was ubicated in second place of forest management priority (Fig. 2). In this case, the anthropogenic impact that has affected the most was the deforestation (Table 1 and Fig. 1). A high forest management priority was observed for Manabí province, 
too (Fig. 2). The results of our study can be related to those exposed in the Homogeneous Deforestation Process Zones project [15], where the deforestation is projected for 2020 based on two variables: stability of the productive landscape (regeneration) during the period 2000-2008 and changes in the population distribution. The resulting projected annual deforestation between 2008 and 2020 for Guayas, Esmeraldas, and Manabí was high (20.35, 13.21 and $8.24 \mathrm{~km}^{2}$, respectively) due to pasture and permanent crops of cocoa, sugar cane, banana, rice, and corn. In comparison to our findings, these three provinces have a high level of management priority mainly due to the high perpetrated deforestation.

$\square$ Deforestation \% $\rightarrow$ - Erosion Index \% $\quad-$ CO2 emissions \% $\quad-$ Organic Carbon

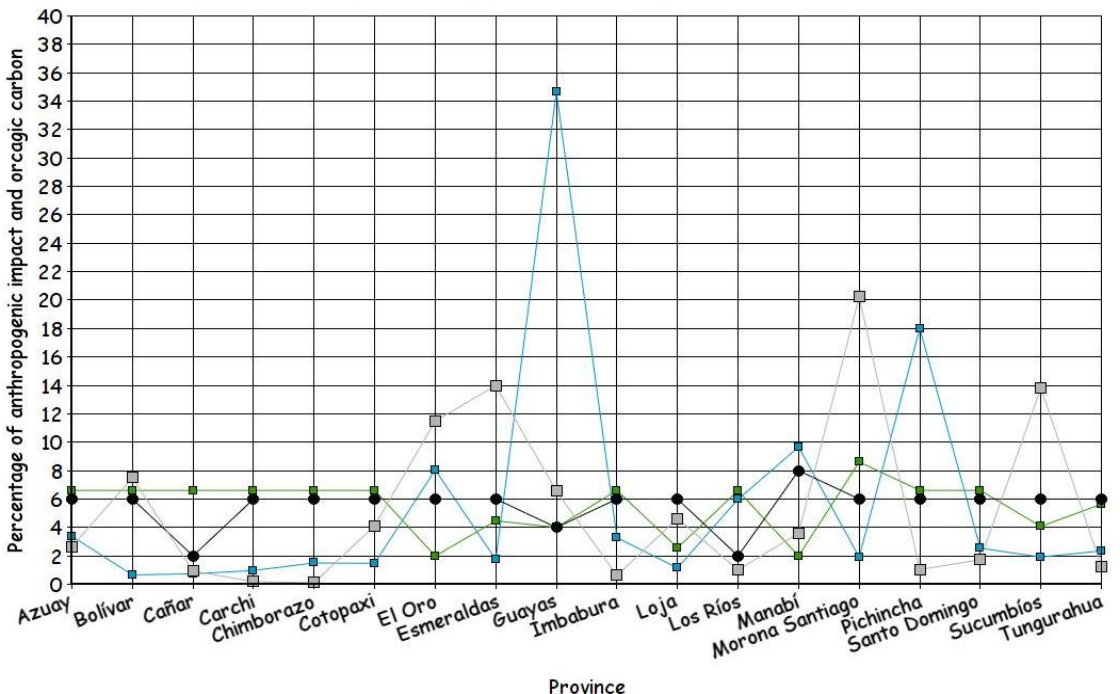

Fig. 1. Anthropogenic impacts (deforestation, soil erosion and $\mathrm{CO}_{2}$ emissions) and organic carbon absorbed by provinces in Ecuador.

In the Amazon region, Sucumbíos and Morona Santiago show a high management priority (Fig. 2). It can be explained by the deforestation as a result of the illegal logging, agricultural activities, and the oil industries that build roads and exploit petroleum. The importance of forest conservation lies in the fact that this region has the Amazon Lowland Evergreen forest with the highest amount of organic carbon (106.4 ton/ha, Figure and Table 1). In the Homogeneous Deforestation Process Zones project [15] the estimated annual deforestation was high not only for Sucumbíos $\left(123.19 \mathrm{Km}^{2}\right)$, but for Morona Santiago $\left(62.27 \mathrm{Km}^{2}\right)$.

A moderate management priority belongs to El Oro and Pichincha provinces. The anthropogenic impacts that mostly affect them are deforestation and $\mathrm{CO}_{2}$ emissions, respectively (Fig. 1). In general terms, the map of forest management priority (Fig. 2) is in line with a spatial model that projects deforested fractions for 2020 [25], where the Coast region (including Guayas, Esmeraldas, and Manabí) has the highest deforested fraction in Ecuador. 


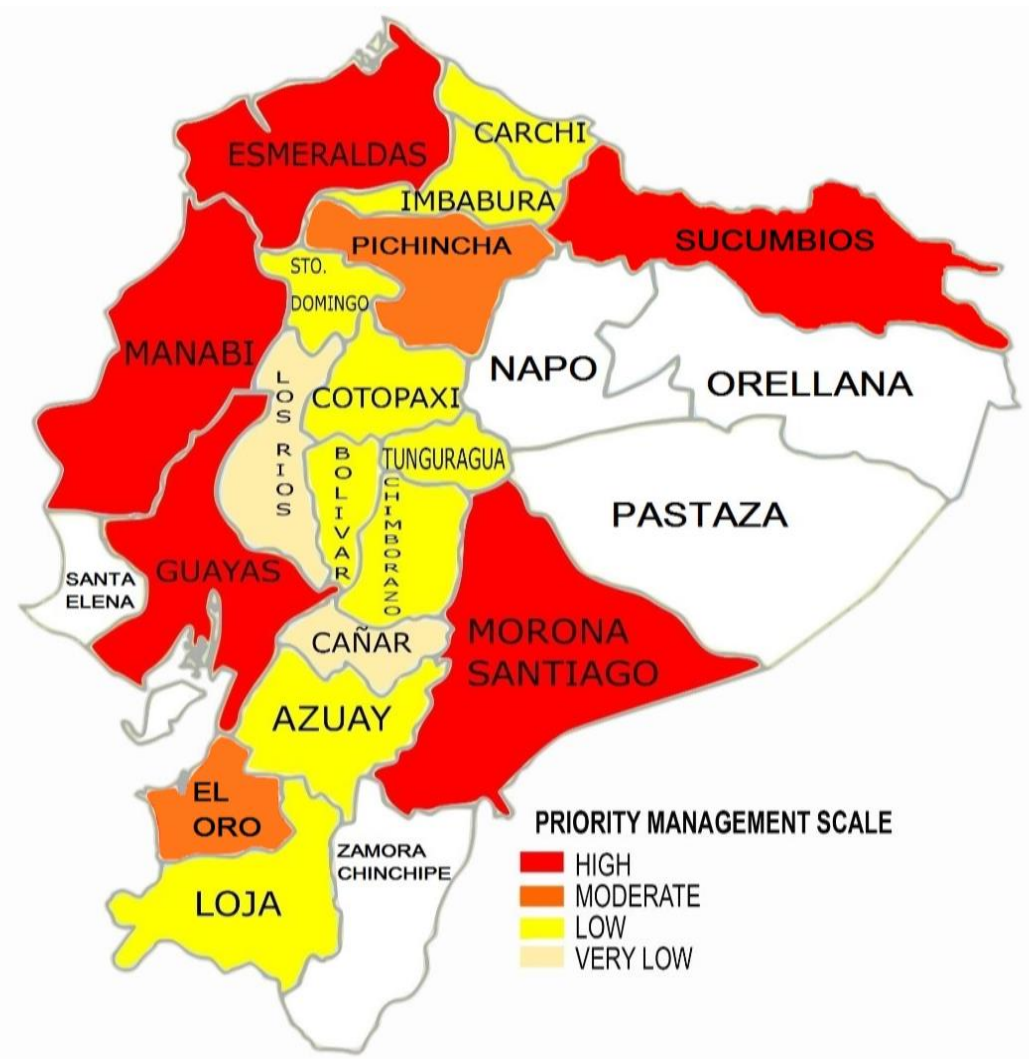

Fig. 2. Map of forest management priority according to environmental indicators of anthropogenic impacts over forest carbon storage in administrative units of Ecuador.

\section{Conclusions}

In accordance with the integrated assessment between the carbon storage capacity of forests and the anthropogenic impacts, we have concluded that the coastal provinces Guayas, Esmeraldas, and Manabí present the highest values 25, 22.85 and 19.9, respectively, which means that the three provinces have a high management priority. A high management priority is also observed in the Amazon region, in the provinces Morona Santiago and Sucumbíos. The Andes or mountains region is mainly characterized by a low management priority. Deforestation, soil erosion, and carbon dioxide emissions were more pronounced on the coast. At the mountains and on the coast, the increase in deforestation was principally due to agriculture and livestock activities. These areas have the potential to retain carbon owing to the high registered carbon storage of 160,4 t/ha in Morona Santiago and 75,8 t/ha in Sucumbíos forests [21]. Furthermore, these forests offer other ecosystem services such as conservation of biodiversity, protection of hydrographic basins and the regulation of regional climates. Thus, it is necessary to conserve them because the stability of forest ecosystem contributes not only to the ecosystem equilibrium of the country, but of the world.

For this reason, we suggest that the government must promote and enhance public policies that encourage access to technical assistance, supplies, improved seeds, and credits. Besides, the intensification of the efficient use of agricultural space to avoid the extensive and unnecessary expansion of the agricultural frontier through deforestation must be 
promoted. The forest monitoring systems can be enhanced in order to protect the areas with high priority of conservation. In addition, we recommend determining the carbon budget of the forests (absorption - emission) that will allow to understand the past behavior, when deforestation had the highest rate, and in this way, to avoid repeating this behavior in the future.

\section{References}

1. G. Magrin, J. Marengo, J. Boulanger, M. Buckeridge, E. Castellanos, G. Poveda, F. Scarano, S. Vicuña, Climate Change 2014: Impacts, Adaptation, and Vulnerability. Cambridge University Press, 1499-1566 (2014)

2. F. Pendrill, U. Persson, J. Godar, T. Kastner, D. Moran, S. Schmidt, R. Glob, Env. C., 56, 1-10 (2019)

3. E. Lugato, P. Smith, P. Borrelli, P. Panagos, C. Ballabio, A. Orgiazzi, A. Jones, Sci. Adv., 4, 11 (2018)

4. UNFCCC. Primera contribución determinada a nivel nacional para el acuerdo de París bajo la convención marco de naciones unidas sobre cambio climático. [First nationally determined contribution to the Paris agreement under the United Nations framework convention on climate change]. URL: https://www4.unfccc.int/sites/ndcstaging/PublishedDocuments/Ecuador\%20First/Prime ra\%20NDC\%20Ecuador.pdf. (2019) Web site (in Spanish).

5. World Resources Institute (WRI). "Climate Watch". URL: https://www.climatewatchdata.org/. (2014)

6. L. Tapia, A.Valverde, C. Terán, C. Rosero, V. Placencia, J. Armijos, M. García, P. Sangoluisa, J. Alvear, M. Chinchero, D. Jiménez, Submission of the Republic of Ecuador to the United Nations Framework Convention on Climate Change. Ecuador's Forest Reference Emission Level for Deforestation. (Quito, 2015). URL: https://redd.unfccc.int/files/2014_december_frel_submission_ecuador.pdf

7. M. Bertzky, C. Ravilious, A. Āraujo, V. Kapos, D. Carrión, M. Chíu, B. Dickson. Carbono, biodiversidad y servicios ecosistémicos: Explorando los beneficios múltiples. [Carbon, biodiversity and ecosystem services : Exploring multiple benefits] (UNEPWCMC, Cambridge, Reino Unido, 2011). (in Spanish).

8. S. Llerena, A. Tarko, A. Kurbatova, P. Kozhevnikova. E3S Web of Conferences, 96, 02002 (EDP Sciences, Les Ulis, 2019).

9. A. Tarko, A. Kurbatova, S. Llerena. E3S Web of Conferences, 116, 00090. (EDP Sciences, Les Ulis, 2019).

10. A.I. Kurbatova, A.M. Tarko. IOP Conference Series: Earth and Environmental Science, 272(2), 022003 (IOP Publishing Ltd, Bristol, 2019)

11. A.I. Kurbatova, A.M. Tarko, H.A. Qdais, E.A. Grigorets, P.V. Kozhevnikova. International Multidisciplinary Scientific GeoConference Surveying Geology and Mining Ecology Management, SGEM, 19(3.2), 633-640 (SGEM, Sofia, 2019).

12. L. Morgan, S. Maxwell, F. Tsao, A. Wilkinson, P. Etnoyer, Marine priority conservation areas: Baja California to the Bering Sea, 125 (Commission for Environmental Cooperation of North America and the Marine Conservation Biology Institute, Montreal, 2005).

13. S. Alvarez, A. Rubio, Rev. Chap., 19, 125-137 (2013).

14. C. Cruz-Huerta, M. González-Guillén, T. Martínez-Trinidad, M. Escalona-Maurice, iFor.-Biogeo. and For. 10, 6, 923 (2017).

15. M. Castro, R. Sierra, O. Calva, J. Caamacho, F. López, Zonas de Procesos Homogéneos de Deforestación del Ecuador: Factores promotores y tendencias al 
2020. [Homogeneous Deforestation Process Zones of Ecuador: Promoting Factors and Trends to 2020] (Quito, 2013) (in Spanish).

16. V. Dmitriev, N. Kaledin. Balt. Reg., 8, 2: 87-98 (2016).

17. V. Dmitriev, V. Kulesh, Y. Sergeev. IOP Conference Series: Earth and Environmental Science 302(1) (IOP Publishing Ltd, Bristol, 2019).

18. MAE. Estadísticas de Patrimonio Natural, datos de bosques, ecosistemas, especies, carbono y deforestación del Ecuador continental. [Natural Heritage statistics, data on forests, ecosystems, species, carbon and deforestation of continental Ecuador]. URL: http://suia.ambiente.gob.ec/documents/10179/346525/ESTADISTICAS +DE+PATRIMONIO+FINAL.pdf/b36fa0a7-0a63-4484-ab3e-e5c3732c284b. (in Spanish).

19. S. Jiménez. La erosión del suelo en el Ecuador. Estudio científico de los indices de erosión en el Ecuador.Observatorio de política ambiental. (2011) (in Spanish).

20. Instituto Nacional de Estadísticas y Censos (INEC). Información Ambiental de los Hogares. [Household Environmental Information]. URL: https://www.ecuadorencifras.gob.ec/documentos/web-inec/Encuestas_Ambientales/ Hogares/Hogares_2015/DOCUMENTO_TECNICO_ENEMDU_MODULO_AMBIEN TAL_2015.pdf. (2011) (in Spanish).

21. FAO. Evaluación de los recursos forestales mundiales 2015. [Global forest resources assessment 2015]. (Roma, 2015). URL: http://www.fao.org/3/a-i4808s.pdf (2015) Web site. (in Spanish).

22. G.G. Azgaldov, A.V. Kostin, V.V. Sadovov, Kvalimetriya dlya vsekh [Qualimetry for all], 165 (2012) (in Russian).

23. S. Hamilton, J. Lovette., PLoS ONE, 10, 3 (2015).

24. D. Segura, D. Jiménez, M. Chinchele, J. Iglesias, A. Sola. XIV Congreso Forestal Mundial (Durban, 2015) (in Spanish).

25. R. Sierra., Patrones y factores de deforestación en el Ecuador continental, 1990-2010. $Y$ un acercamiento a los próximos 10 años. [Deforestation patterns and factors in continental Ecuador, 1990-2010. And an approach to the next 10 years]. Conservación Internacional Ecuador y Forest Trends (Quito, 2013). URL: https://www.foresttrends.org/wp-content/uploads/2013/03/rsierra_deforestacionecuador19502020_180313-pdf.pdf (in Spanish) 